\title{
Predation of Five Generalist Predators on Brown Planthopper (Nilaparvata lugens Stål)
}

\author{
SRI KARINDAH \\ Department of Plant Pest and Diseases, \\ Faculty of Agriculture, Brawijaya University \\ Jalan Veteran Malang 65145 \\ (received March 2011, accepted August 2011)
}

\begin{abstract}
ABSTRAK
Predasi Lima Predator Generalis pada Wereng Coklat (Nilaparvata lugens Stål). Metioche vittaticollis dan Anaxipha longipennis (Orthoptera: Gryllidae) adalah predator generalis di habitat sawah yang belum banyak diteliti di Indonesia. Pada penelitian ini diamati dan dibandingkan daya mangsa kedua predator tersebut dengan Paederus fuscipes (Staphylinidae), Ophionea sp. (Carabidae) dan Micraspis sp. (Coccinellidae) pada nimfa wereng batang coklat Nilaparvata lugens (instar ke- 4 dan ke- 5) di laboratorium. Sebanyak 20 nimfa $N$. lugens diberikan pada masing-masing predator selama 2 jam dan pemberian mangsa dilakukan selama 5 hari berturut-turut. $M$. vittaticollis memangsa nimfa wereng batang coklat paling banyak dan selanjutnya diikuti berturut-turut oleh A. longipennis, Micraspis sp., P. fuscipes, dan Ophionea sp. Daya mangsa $M$. vittaticollis dan A. longipennis lebih tinggi daripada ketiga predator yang lain. Micraspis sp. lebih aktif memangsa pada pagi hari, sedangkan $M$. vittaticolis, A. longipennis, P. fuscipes dan Ophionea sp. lebih aktif memangsa pada pagi dan malam hari. Kelima species predator tersebut tidak aktif memangsa pada siang hari. Dengan melihat kemampuan mempredasinya yang tinggi, suatu usaha yang sungguh-sungguh perlu dilakukan untuk melestarikan predator-predator tersebut, khususnya $M$. vittaticollis dan $A$. longipennis.
\end{abstract}

KATA KUNCI: Konsumsi mangsa, Metioche vittaticollis, Anaxipha longipennis

\begin{abstract}
Predation of Five Generalist Predators on Brown Planthopper (Nilaparvata lugens Stål). Two generalist predators of brown planthopper, Metioche vittaticollis and Anaxipha longipennis (Gryllidae) have not been much studied in Indonesia. This research was conducted to study and compare the predatory ability of $M$. vittaticollis, A. longipennis (Gryllidae) and three coleopterans, Paederus fuscipes (Staphylinidae), Ophionea sp. (Carabidae), and Micraspis sp. (Coccinellidae) against brown planthopper (fourth and fifth instars) under laboratory condition. In total, 20 nymphs of $N$. lugens were exposed for 2 hour to each predator for 5 consecutive days. Prey consumptions by the predatory crickets, $M$. vittaticollis and A. longipennis were greater than the other predators and followed by A. longipennis, Micraspis sp., P. fuscipes, and Ophionea sp. respectively.
\end{abstract}

\footnotetext{
*Korespondensi:

Telp.: +62-341-575843, Faks: +62-341-569237,

E-mail: karindah@ub.ac.id
} 
Consumption rates of $M$. vittaticolis and A. longipenis were also higher than other predators. Micraspis sp was more active on predation in the morning, while $M$. vittaticollis, A. longipennis, P. fuscipes, and Ophionea sp. were more active both in the morning and the night but not in the afternoon. However, all five species of predators were not so active in preying during the afternoon. In conclusion, a major effort should be extended to conserve these predatory crickets especially $M$. vittaticollis and A. longipennis.

KEY WORDS: Prey consumption, Metioche vittaticollis, Anaxipha longipennis

\section{INTRODUCTION}

Brown planthopper Nilaparvata lugens Stål is distributed throughout India, South East Asia and China. The insect was previously considered to be a minor pest throughout its range, and still is in a number of countries. However, since 1970's the significance of this species as a pest increased considerably in Indonesia (Kalshoven 1981; Soenarjo 2000). In 1961-1970, 52,000 ha of rice field was attacked by brown planthopper, and in the decade of 1971-1980, over 2,500,000 ha of rice fields was attacked. In 2005 planting season, brown planthopper's attack was over 46,000 ha in Java (BBPADI 2011). N. lugens causes 'hopper burn' of rice plants by direct feeding and transmitting the Grassy Stunt and Ragged Stunt rice diseases (Kalshoven 1981). The rice brown planthopper is an insecticide-induced resurgence pest whose degree of damage is positively correlated to insecticide use (Chiu 1979). Cultural practices and resistance varieties of rice are suggested in controlling this pest. However, bio- logical control should also be considered.

Predators, parasites and pathogens play a major role in the regulation of rice pests (van Vreden and Ahmadzabidi 1986). Brown planthopper has a natural enemies complex which may keep this pest below economic damage level most of the time. The brown planthopper's natural enemies complex consists of parasitoids, specialist and generalist predators, and pathogens. One species of nematode, 15 species of insects and spiders, and 8 pathogens have been recorded as natural enemies and diseases of this pest (Mochida et al. 1979; Kalshoven 1981). Cyrtorhinus longipennis, Harmonia spp. Paederus fuscipes Curtis (Staphylinidae), Ophionea nigrofasciata (SchmidtGoebel) (Carabidae), Micraspis sp. (Mulsant) (Coccinellidae) and the orthopterans Metioche vittaticollis (Stål), Anaxipha longipennis (Serville) (Gryllidae) and Conocephalus longipennis (Tettigoniidae) are known as the predator of rice hoppers (Shepard et al. 1987). Pardosa pseudoannulata Boesenberg, Tetragnatha maxillosa Thorell, Cyrtorhinus lividipennis Reuter, and Conocephalous longipennis de 
Haan had high ability to suppress the population of $N$. lugens on rice, the predation capacity were $4.05,3.10$, and 1.79 brown planthoppers per day respectively (Marheni 2004).

There is a renewed interest in biological control exercised by assemblages of mainly generalist predators (Symondson et al. 2002). Settle et al. (1996) have studied the relative abundance of generalist predators in the rice field in Java. The high population of generalist predators in the early season, which were supported by detritus feeding and plankton feeding insects before the pest populations developed, should suppress pest populations and lend stability to rice ecosystems. The potential preying of some spider and coleopterans predator such as $P$. fuscipes, $O$. nigrofasciata, Micraspis sp. (Verania sp.) P. pseudoannulata, and T. maxillosa have been much studied in Indonesia (Laba 1999; Laba et al. 2001; Marheni 2004), excepted $M$. vittaticollis and $A$. longipennis. Since the importance of generalist predators of brown planthopper, especially $M$. vittaticollis, and A. longipennis, has not been known in Indonesia, a study was conducted to compare the predatory ability of these orthopterans and three coleopterans against brown planthopper in the laboratory.

\section{MATERIALS AND METHODS}

The laboratory experiment was conducted between April and June 2005, at the Laboratory of Entomology, Brawijaya University in Malang. In the laboratory, temperature was ranged from $24^{\circ}$ to $27^{\circ} \mathrm{C}$.

Five predator species were selected for cage tests on brown planthopper acceptance and consumption: the coleopterans Paederus fuscipes (Staphylinidae), Ophionea sp. (Carabidae), and Micraspis sp. (Coccinellidae) and the orthopterans Metioche vittaticollis, and Anaxipha longipennis. The predators were collected from Tasikmadu District, Malang, East Java and were starved individually in Mylar cage test for 24 hours prior to the experiment. Unsexed individuals were used in the test, except for $M$. vittaticollis and A. longipennis, for which were used only female adults.

The consumption rates were determined separately for five predator species. One predator was introduced to a cylindrical Mylar cage $(10 \mathrm{~cm}$ diameter and $28 \mathrm{~cm}$ height) with IR64 rice seedlings variety, and provided 20 fourth-fifth nymphs of brown planthopper. The prey consumed was recorded four times for one day-period. The numbers of brown planthoppers were replaced to the original density after 24 hours. The consumption rate experiments for each predator species was replicated 10 times and determined daily within 5 days. 
As a measure of prey acceptability, an acceptance ratio was calculated being the proportion of predators that consumed at least one prey of the provided prey (de Kraker et al. 2000) over the entire 5-day period. Test for significance of the treatments was carried out using Two-ways ANOVA and means were compared by Tukey's test.

\section{RESULTS AND DISCUSSION}

The laboratory study showed that all five species of predators consumed brown planthopper nymphs when offered in a no-choice situation. The prey acceptance and the number of nymphs consumed or killed per day are presented in Table 1. The five predators accepted brown planthopper nymphs as prey in each replication. Based on brown planthopper nymphs consumption rates, a ranking was made and it was found that $M$. vittaticollis consumed more than A. longipennis and followed by Micraspis sp., $P$. fuscipes, and Ophionea sp. There was a significant overall difference in pre- dator consumption between five predators. The average number of brown planthopper nymphs which were consumed by $P$. fuscipes and Ophionea sp. was not significantly different. Micraspis sp. consumed significantly greater numbers of brown planthopper nymphs than $P$. fuscipes or Ophionea sp. Whereas M. vittaticollis and A. longipennis consumed higher numbers of prey than $P$. fuscipes, Ophionea sp. or Micraspis sp. Consumptiom behavior of the crikets varies; i.e. from preying on the whole body of brown planthopper nymph to only biting on some. Each cricket was able to kill more than that they might consume per day.

The daily pattern in preying of the five species predatory insects is shown in figure 1. It has been observed that the predators never stop preying during a day; there was a period of time that they decreased the predation and increased after some time. A. longipennis, $M$. vittaticolis, $P$. fuscipes and Ophionea sp. might have the same pattern in preying. They were more active in preying after dusk until early

Table 1. Prey consumption rates and acceptance ratio of rice field predators of brown planthopper in the laboratory

\begin{tabular}{lrc}
\hline \hline \multicolumn{1}{c}{ Predator species } & $\begin{array}{c}\text { Nymphs consumed/killed per day } \pm \\
\text { S.E. }\end{array}$ & Prey acceptance ratio \\
\hline Ophionea $\mathrm{sp}$. & $4.36 \pm 0.22 \mathrm{a}$ & 1 \\
P. fuscipes & $4.06 \pm 0.30 \mathrm{a}$ & 1 \\
Micraspis $\mathrm{sp}$. & $8.44 \pm 2.08 \mathrm{~b}$ & 1 \\
A. longipennis & $11.78 \pm 0.48 \mathrm{c}$ & 1 \\
M. vittaticollis & $14.38 \pm 0.36 \mathrm{~d}$ & 1 \\
\hline *) In a column, means followed by a common letter are not significantly different \\
\multicolumn{2}{l}{ at the $\mathrm{p}=0,05$ by Tukey' Test }
\end{tabular}




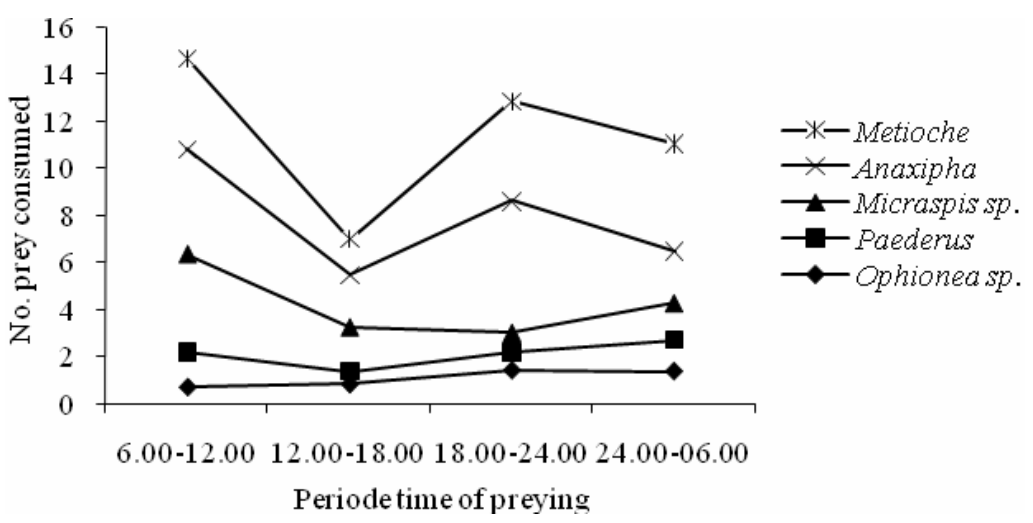

Figure 1. Numbers of Nilaparvata lugens nymphs consumed by five predator in 24-hour period

morning and decreasing in the afternoon. Micraspis sp. was more active in preying during daytime, unlike $A$. longipennis, M. vittaticolis, $P$. fuscipes and Ophionea sp. All the five species of predators were not too active in preying in the afternoon.

The present findings depicted the predation potential of common generalist predators in rice habitat. The data indicated that the predatory crickets $M$. vittaticollis and A. longipennis consumed greater than the other predators. The amount of feeding by $M$. vittaticollis in present finding was found two-three times more than consumption capacity of $P$. fuscipes, and Ophionea sp. However, this consumption rate was different than the result found by Rubia and Shepard (1987), that the cricket predator consumed lower number of brown planthopper nymphs of two to fourth instar nymph. DeKraker (1996) also found the low consumption of $M$. vittaticollis on brown planthopper nymphs, and this cricket preferred prey egg type rather than nymph or larvae. According to deKraker (1996), P. fuscipes, and Ophionea sp. consumed few leaffolder eggs in the petridish test compared with M. vittaticollis, A. longipennis, or Micraspis sp. Laba (1999) found that $P$. fuscipes, and Ophionea sp. consumed 4.9 and 2.7 brown planthopper per day respectively. This was showed that they had lower predation ability rather than M. vittaticollis, A. longipennis, or Micraspis sp. However, according to Laba et al. (2001) Micraspis sp. consumed 2.8 brown planthopper per day which was lower than P. fuscipes, and Ophionea sp. This was the opposite result with this experiment when Micraspis sp. consumed brown planthopper more than P. fuscipes, and Ophionea sp. The coccinellid predators, e.g. Micraspis sp., are usually very abundant during the flowering stage of the crop and the availability of pollen will 
probably reduce their impact on brown planthopper (deKraker 1996), M. vitaticollis never used plant as the source of their food. M. vittaticollis was the most voracious predator, followed by A. longipennis, O. nigrofasciata, Micraspis nr.crocea and $P$. fuscipes (den Berg et al. 1992), therefore keep them as appropriate effective biological control agents, particularly on brown planthopper.

There was a period of time that the five predators decreased and increased the predation after some time. The five species predators have different pattern in preying during a day, they would be preying all day when the preys were available. A. longipennis, M. vittaticolis, are active at night (deKraker 1996) as well as $P$. fuscipes (Laba 1999) that they might have the same pattern in preying. They were more active in preying after dusk until early morning and decreasing in the afternoon. However, A. longipennis, and $M$. vittaticolis increased more prey consumed at two period of time in the evening and in the early morning, then after sometime they decreased in preying. Micraspis sp. was more active in preying during daytime, unlike A. longipennis, $M$. vittaticolis, $P$. fuscipes and Ophionea sp. However, all the five species of predators were not too active in preying in the afternoon.

A degree of caution is needed in relating the findings of this laboratory study using artificial arenas to field situations and it is evident that these results require confirmation in large scale field studies. However this study demonstrated the high potential of two predatory crickets $M$. vittaticollis and A. longipennis as generalist predator in rice habitat. Therefore a major effort should be extended to conserve the predatory crickets $M$. vittaticollis and A. longipennis through judicious use of chemicals and perhaps habitat manipulation.

\section{CONCLUSION}

There was evidence to conclude that the consumption rates of five species predators on brown planthopper nymphs ranked from the highest to the lowest: M. vittaticollis, A. longipennis, Micraspis sp., $P$. fuscipes, and Ophionea sp. respectively.

Micraspis sp. was more active in preying during daytime, unlike $A$. longipennis, $M$. vittaticolis, $P$. fuscipes and Ophionea sp. However, all the five species of predators were not too active in preying in the afternoon

$M$. vittaticolis and $A$. longipennis were also active preying longer than Micraspis sp., P. fuscipes and Ophionea $\mathrm{sp}$.

\section{ACKNOWLEDGEMENT}

I would like to thank Dwi, for helping in rearing of brown planthopper and predators used in the experiments. 


\section{REFERENCES}

BBPADI. 2011. Wereng coklat. http: //bbpadi.litbang.deptan.go.id/ind ex.php?option=comcontent $\&$ vie $\mathrm{w}=$ article $\& \mathrm{id}=228 \% 3 \mathrm{~A}-\mathrm{werengc}$ oklat\&catid $=60 \% 3$ Ahamapadi $\&$ I temid $=98 \&$ lang $=$ in. [accessed in 28 Juni 2011]

Chiu SC. 1979. Biological control of the brown planthopper. In Brown Planthopper: Threat to Rice Production in Asia. LosBanos, The Philippines: International Rice Research Institute. $p$ 335-355.

de Kraker J. 1996. The Potential of Natural Enemies to Suppress Rice Leaffolder Populations [thesis]. Nederland: Landbouw Universiteit Wageningen. p 257.

de Kraker JA, van Huis JC, van Lenteren KL, Heong, and Rabbinge R. 2000. Identity and relative importance of egg predators of rice leaffolders (Lepidoptera: Pyralidae). Biological Control 19:215-222.

Kalshoven LGE. 1981. Pest of Crops in Indonesia. Revised by P.A. Van der Laan. Jakarta: PT. Ichtiar baru, Van Hoeve. translation of: Deplagen van de Cultuurgewasen in Indonesie.

Laba IW. 1999. Aspek biologi dan potensi beberapa predator hama wereng pada tanaman padi. Jurnal Penelitian dan Pengebangan Pertanian 18(2):56-62

Laba IW, Alwi A, dan Baringbing B. 2001. Peranan gulma dalam pelestarian parasitoid dan predator menuju sistem pertanian berke- lanjutan. Di dalam: Prosiding Konferensi Nasional XV, Himpunan Ilmu Gulma Indonesia, Himpunan Ilmu Gulma Indonesia; Surakarta, 17-19 Juli 2001. Surakarta: HIGI. p 20.

Marheni. 2004. Kemampuan beberapa predator pada pengendalian wereng batang coklat (Nilaparvata lugens Stål). Jurnal Natur Indonesia. 6(2):84-86

Mochida O, Denan K. and Astuti ED. 1979. Some observation on the bionomics of the Brown Planthopper Nilaparvata lugens Stål (Homoptera: Delphacidae). Di dalam: Kongres Entomologi I, Jakarta 9-11 January 1979. Jakarta: PEI. p 13

Rubia EG, and Shepard BM. 1987. Biology of Metioche vittaticollis Stål (Orthoptera: Gryllidae), a predator of rice pests. Bull. Ent. Res. 77:669-676.

Settle WH, Ariawan H, Astuti ET, Cahyana W, Hakim AL, Hindayana D, Lestari AS, Pajarningsih and Sartanto. 1996. Management tropical rice pests through conservation of generalist natural enemies and alternative prey. Ecology 77(7):1975-1988.

Shepard BM, Barrion AT, and Litsinger JA. 1987. Helpful Insects, Spiders and Pathogens. Friend's of The Rice Farmer. Los-Banos, The Philippines: International Rice Research Institute. p 127.

Soenarjo E. 2000. Analisis Ledakan dan Pengendalian Hama Wereng Coklat di Wilayah Endemik. Pusat Penelitian dan Pengem- 
bangan Tanaman Pangan. Jakarta: Badan Penelitian dan Pengembangan Pertanian.

Symondson WOC, Sunderland KD, and Greenstone MH. 2002. Can ge-neralist predators be effective biocontrol agents? Ann. Rev. Entomol. 47:561-594.

Van DenBerg H, Litsinger JA, Shepard BM, and Pantua PC. 1992. Acceptance of eggs of Rivula atimeta, Naranga aenescens (Lepidoptera: Noctuidae) and Hydrellia philippina (Diptera: Ephydridae) by insect predators on rice. Biocontrol 37(1):21-28.

Van Vreden G. and Ahmadzabidi AL. 1986. Pest of Rice and Their Natural Enemies in Peninsular Malaysia. The Nederland: Pudoc Wageningen. p 18. 